\title{
Impact of Accounting Skills on Entrepreneurship Education for Self-Reliance and Sustainable Development: A Study of Selected Small Scale Business in Owerri Municipal Imo State
}

\author{
Nwaigburu K.0 \\ Department Of Accountancy \\ Alvan Ikoku Federal College of Eduction, Owerri-Imo State, Nigeria \\ Eneogwe, V.N \\ Department Of Business Education National Open University of Nigeria, \\ Lagos-Nigeria
}

\section{Doi:10.5901/mjss.2013.v4n16p81}

\begin{abstract}
Accounting skill was found to be contributory to entrepreneurial performance and as such entrepreneurs are advised to embark on capacity building in accounting skill in the area of financial management and record keeping. Entrepreneurs are agents and drivers of development in most economies of the world including Nigeria. The entrepreneur establishes his presence through the formation of a small and medium scale enterprise (SME). Accounting on its part, is of great importance to the development of small and medium scale enterprises. Arguably, accounting is the core academic discipline that aids the entrepreneurial drive given the popular opinion that is the language of business. The objectives of this study is to examine the role of accounting on entrepreneurship education for self- reliance and sustainable development in Nigeria. The study considered the accounting profession and the major role it plays in entrepreneurship development. It is the submission of the authors that entrepreneurs with basic accounting knowledge and entrepreneurial skills stand better chances of becoming self- reliant and attaining business success. The paper recommends among other things that government should remove those obstacles that militate against entrepreneurial development in Nigeria.
\end{abstract}

Keywords: Accounting skill, Entrepreneurship Education, Small -Scale Business, Self - Reliance and Sustainability.

\section{Introduction}

Entrepreneurship started to gain ground in Nigeria as a result of the prevalence of unemployment of our youths after schooling. Many of our youths who could not embark on higher education after secondary school cannot be absorbed for paid employment both by the government and the private sector. In the same manner, many graduates from the universities, after the one year compulsory National Youth services start searching for unavailable jobs.

It is obvious that the government cannot employ all the graduate job seekers the only way to tackle this problem is to be self- reliant and job employers and not job seekers. The basic freedoms of capitalism according to Kanu and Nwaiwu (2010:2) are the opportunity for private property. There are important group of individuals that play essential roles in capitalism these are the entrepreneurs, mangers, workers and consumers.

The entrepreneurs required accounting and other skills for proper management of their business. In the words of Akands (2011)" for any small scale enterprise to be successful, owners of business must posses appropriate skills and abilities to run the business. It is therefore very important for entrepreneurs in Nigeria to 
develop all necessary skills required for setting and effective running of the enterprise in order to contribute meaningful to development and self- reliance of the nation's economy.

To succeed in today's competitive market as an entrepreneur, one needs a broad array of entrepreneurial skills. Akande (2011) also argued that entrepreneurial skills are those qualities or attributes required for an entrepreneur to start and successfully mange a business in a competitive environment.

From the forgoing analysis, it becomes clear that business owners need to poses basic skills necessary to start, develop, fiancé and market their business. It also implies that inability to install a proper accounting system would disallow business monitoring reporting and performance evaluation that are required for business survival. Many entrepreneurs have failed in the past probably for ignoring this important measurement apparatus.

This paper therefore focuses on the impact of accounting skills on the performance of entrepreneurs in Owerri capital territory.

\section{Problem of the Study}

For any organization to function effectively including small business firms, it requires leadership and decision making. Unfortunately, many of our entrepreneurs fail to succeed because of neglect of accounting skills. The problem of the study stresses on how can entrepreneurs enhance their performance without accounting skills. This paper therefore proffers solution to the above problem.

\section{Purpose of the Study}

To determine how accounting skills can improve entrepreneurship in Nigeria.

\section{Research Question}

How can accounting skills improve the performance of entrepreneurs in Nigeria?

\section{Hypothesis}

Hypothesis was formulated and tested at 0.05 level of significance.

$\mathrm{HO}$ : Possession of a proper accounting skill by entrepreneurs will not significantly improve their performance.

Hi: Possession of a proper accounting skill by entrepreneurs will significantly improve their performance.

\section{Review of Related Literature}

Entrepreneurship stimulates economic development, thus contributing to the transformation of the traditional sector into a modern one, creation of employment, reducing rural and urban migration and serving as a training ground for managerial skill acquisitions. Entrepreneurs are found in many small scale business. In the words of Eke (2007), "Small business accounts for over $90 \%$ of the entrepreneurs in Nigeria, small scale entrepreneurs in Japan accounted for about $98.5 \%$ of the non- primary business establishments, employing $79.1 \%$ of the country's labour force and contributing $50.8 \%$ of the shipment".

In his contribution, Owuala (1987), argues that economic development is a factor of industrialization, characterized by increasing growth of small scale enterprises (SSES). These SSEs make invaluable contributions to the economics of both more developed countries (MDCs) and less Developed Countries (LDCs) 


\section{Qualities and Skills for Entrepreneurial Success}

It take certain qualities and skills to make a successful entrepreneur. A new venture is risky and will demand time and resources, both personal and professional, but with a strong inner drive and some of the qualities as advocated below by Fijo and Obi (2012), success is sure; an entrepreneur ought to be;

- Committed . determined and persevering.

- Confident, vision driven.

- Creative and innovative

- Willing to work hard

- Able to handle responsibilities

- Goal- oriented and self- confident

- Action - oriented and good leader.

- Problem solver and self- reliant

- Willing to take calculated risk

- Realist and quick learner.

- Open to feed back. Etc.

Being a successful entrepreneur is not an easy task, itemizing what is takes to be an entrepreneur could be an in excusable list. No matter the kind of entrepreneur, entrepreneurial vision is very necessary. An entrepreneur must have a formal, written business plan, and must concentrate on his mission statement: that guides him or her adequately.

\section{Link Between Entreprenurship and Self Reliance}

Entrepreneurship which involves recognizing a business opportunity, mobilizing resources and persisting to exploit that opportunity is a necessary ingredient for self- employment. Employment creation and the boosting of income - opportunity are some of Nigeria's top challenges today. The Federal Government Policies and strategies are now being geared to encourage and support the private sectors in generating growth in selfemployment through the introduction of entrepreneurship development. What it simply means is that if these government policies and strategies are properly implemented, our educational system will now produce graduates who will be job creators, rather than job seekers. Entrepreneurship prepares people to be responsible, enterprising individuals who become entrepreneurs or entrepreneurial thinkers and contribute to economic development and sustainable communities, and thus become self- Reliant.

According to Medayese (2010:1), a self- reliant person is one who is self- employed, because selfemployment is one of the keys to work out of poverty. The benefit of being self- reliant through entrepreneurship can never be over- emphasized because entrepreneurship is the backbone of many great and developed nations today, such as China, United states of America, Japan etc. Consequently, selfreliance can not be achieved in an atmosphere where entrepreneurial activities are lacking, hence entrepreneurship is a strong acquisition programme that will help people of a country like Nigeria become better and greater.

\section{Entrepreneurship Education}

Education can be described as the process by which knowledge, skills, values and desirable attitudes are transmitted to members of a society to enable them contribute meaningfully to its development and sustenance. Thus, education is seen as the bedrock of any national development. Entrepreneurship education according to Gimah and Umuigbokhai (2011) seeks to prepare people, especially youths, to be responsible, enterprising individuals who become entrepreneurs. The international Labour Organization (ILO) 
defined entrepreneurship education as a type of education that equips the responding to environmental challenges. It is heart warming to note that the new National Policy on Education emphasizes entrepreneurship education.

\section{Objectives of Entrepreneurship Education}

Entrepreneurship education according to Paul (2005) is structured to achieve among others, the following objectives.

1. To offer functional education to the youths that will enable them to be self- employed and selfreliant.

2. To provide young graduates with adequate training that will enable them to be creative and innovative in identifying new business opportunities.

3. To serve as a catalyst for economic growth and development.

4. To reduce high rate of poverty.

5. Reduction in rural - urban migration.

\section{Small and Medium Scale Entreprises (SMES)}

Small and medium scale enterprises (SMEs) are catalysts in the socio- economic development of any country. According to Onuoha (1997) the economic prosperity of Nigeria lies in the dynamism and growth of entrepreneurs and SMEs. The catalytic roles of SMEs as indicated earlier, have been amply displaced in all the newly industrialized countries of South East Asia, commonly referred to as Asian Tigers.

The Federal Government of Nigeria has long recognized the need to promote the development of SME's in order to stimulate employment, mobilize local resources, reduce migration from rural to urban areas and disperse industrial enterprises more evenly across the country. This is why the government has established institutions to promote SMEs. These institutions according to Izedonmi (2008) include small and medium industries Equity Investment Scheme (SMIEIS), Small Scale Industry credit Scheme (SSICS), Small and Medium Enterprises Development Agency of Nigeria (SMEDAN) etc. Government efforts at promoting the development of SMSs in the country have yielded mixed results. Today, the entrepreneur and SMEs in Nigeria are face with myriad of challenges, which include.

* Harsh and unfriendly business environment:

* Unfriendly government policies

* Lack of access to funds

* Poor management

* Mismanagement of funds

* Constant power outage

* Book- keeping problem etc.

\section{The Accounting Profession / Skills}

The accounting profession has been described as the backbone of our societal life. This is because in the words of Nnadi (1991) business organizations use accounting information to plan and control their activities and to report the results of these activities to shareholders, creditors, labour unions and government agencies. Non- profit organizations such as churches, town unions and clubs also use accounting information for planning, conducting and reporting their activities. The Federal, State, Local Governments and other government agencies use accounting information in similar ways. According to Adegite (2010) the accounting profession speaks the language of business as it record all transactions of organizations that have monetary implications. Thus accounting is that discipline that involves the systematic gathering, classification, 
recording, analysis, interpretation and transmission of information to assist users make economic decision. The accounting profession according to Evbodaghe (2009) has been responsible for the spread of financial knowledge and for a commitment to help business and non- business organizations develop the capacity to success. Even at the global level, the international accountancy profession has helped several countries to build stronger and more stable economies. In fact the profession is empowered by investor confidence and public trust without which the credibility of the information prepared and presented by the management of the organization will be at risk. In Nigeria, the practice of accounting is guided by the code of conduct of the institute of chartered Accountant of Nigeria (ICAN) and code of Ethics of the Association of National Accountants of Nigeria (ANAN)- the two legally recognized accounting bodies in Nigeria. According to Ajibolade (2008) the ICAN code of Conduct and ANAN code of Ethics are devoted to such ethical issues as integrity, transparency and accountability.

Accounting skills are the totally of skills ranging from record keeping, attention directing, financial management and reporting skills that are expected to promote effective decision, performance evaluation and business reporting of any business enterprise, (Akande 2011). He further stated that attention directing skill enables the owner manager to make vital decision on production and pricing issues while reporting skill describes the method, and technique by which business information are reported to the stakeholders of the business.

According to the Accounting Education Change Commission (AECC 1990) to be successful in their careers, accounting graduates need skills and abilities that beyond accounting technical knowledge, they include communication skills, analytical skills and interpersonal skills. Accounting graduates are also expected to be able to receive and send information, identify and solve unstructured problems in unfamiliar settings and exercise judgment, Agbiogwu (2010) highlighted nine (9) common traits to entrepreneurs besides accounting skills.

They are as follows;

- Physical and mental stamina

- A desire to take control of their own destiny

- A competitive instinct

- Resilience in the face of defeat

- Good Judgment

- Decisiveness

- The ability to inspire others

- An unfailing positive attitude

- Great communication skills.

\subsection{Managing business Finances}

One way of keeping tabs on the flow of money is through accounting. By accounting, we mean a system used to record, classify, summarise and interpret the financial data of a business (Brown \& Clow 1992).

They further stated that the financial data are made up of the transactions that occur in the daily operations of the business. A good entrepreneur should be able to be conversant with common sources and uses of funds in a business. The diagram below shows the various sources and used of funds in a typical business. 
Fig 1.

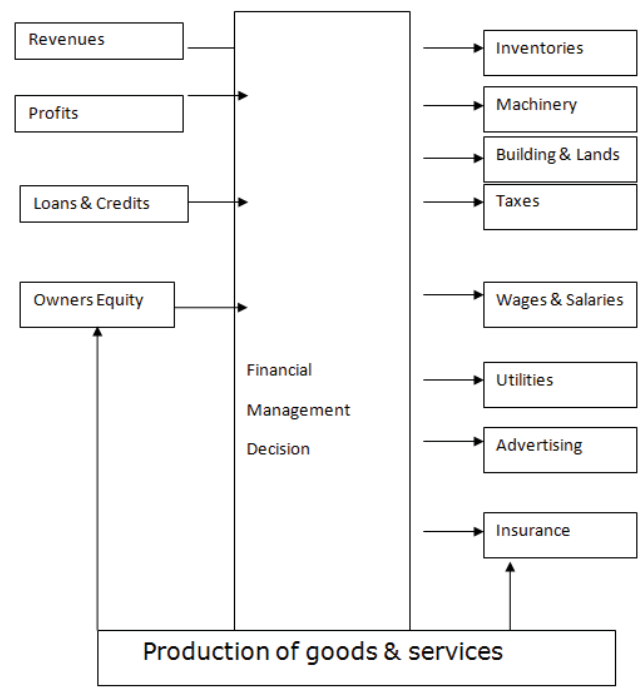

Source: B.J \& Low , K. W (1992:153) Introduction to business, our Business and Economics World, California Macmillan/ McGraw Hill.

\section{Methodology}

This paper focuses on the research, techniques adopted and used for this study with the aim of achieveing the research objective. Survey research design is adopted in this study. This method was chosen because the sampled elements and the variables the are being studied are simply being observed as they are without making any attempt to control or manipulate them. Data were collected from a sample of entrepreneurs to determine the impact of accounting skills on the performance of entrepreneurs in Owerri capital territory.

However, the study was restricted to Owerri Municipal Imo State. Primary method of data collection was used in this study. It consists of items in well- structured non- disguised questionnaire that was administered to and completed by the respondents. The respondents returned althea 100 questionnaire personally administered. Data collected were analyzed with the use of chi- square.

Table 2: Chi- square computation of Hypothesis one

\begin{tabular}{|c|c|c|c|c|}
\hline $\mathrm{FO}$ & $\mathrm{Fe}$ & $\mathrm{F} 0-\mathrm{Fe}$ & $(\mathrm{Fo}-\mathrm{Fe})^{2}$ & $\frac{(\mathrm{Fo}-\mathrm{Fe})^{2}}{\mathrm{Fe}}$ \\
\hline 65 & 50 & 15 & & 4.50 \\
\hline 60 & 50 & -10 & & 2.00 \\
\hline 58 & 50 & -2 & & 0.08 \\
\hline 62 & 50 & 2 & & 0.08 \\
\hline 55 & 50 & 5 & & 0.50 \\
\hline 40 & 50 & -10 & & 2.00 \\
\hline & & & $\mathrm{X}^{2}$ & 9.16 \\
\hline
\end{tabular}

N/B

Degree of freedom $=\mathrm{df}=2$

Significant Level $=0.05$ 
Decision

Calculated $X^{2}=9.16$

Table - Value $\left(X^{2}\right)=2.991$

We reject $\mathrm{Ho}$ and accept the $\mathrm{Hi}$, hence we conclude that accounting skills has a great impact on entrepreneurship and performance of business.

\section{Relevance of Accounting to Enterpreneurship Education and SMEs.}

The relevance of accounting to entrepreneurs and SMEs can be better appreciated when one considers its role in business management. These contributions are summarized hereunder.

1. Accounting has been described as "the language of business" as it record all transactions of organizations that have monetary implications.

2. Accounting provides financial information, on the basis of which business organizations plan and control their operations as well we make decisions.

3. It is not an exaggeration to state that men and women in business and government are stronger in their perception of business when they have basic accounting knowledge. Little wonder that Horngren (1995) has aptly noted that the learned of accounting is almost always a wise investment.

4. Accounting provides answers to two important question: (1) How well has the business performed over a given period of time? (2) what is the financial position of the business at a given point in time? The answers to the above questions are provided through the preparation of the profit and loss account and balance sheet.

5. Accounting is of great importance in the analysis and interpretation of final accounts in order to assess the financial condition and commercial soundness of the business to which the account relate.

6. A good accounting system will ensure that error and fraud are detected as soon as possible.

7. From the foregoing, it is clear that accounting has contributed and will continue to contribute to business success.

\section{Conclusion}

Entrepreneurship is agent of transformation with reference to creation of employment, reducing rural- urban migration and serving as a training ground for managerial skill acquisition. Accounting skills are highly contributory to entrepreneurial performance and is therefore required to be possesses by owner managers for effective small business development in Owerri Municipal Imo State in particular and Nigeria as a whole.

\section{Recommendations}

This paper proffers the following recommendations;

- Entrepreneurs should embark on capacity building in accounting skill in the area of financial management and record keeping for better performance.

- Government at all levels should encourage entrepreneurship education and training for entrepreneurs and SMES.

- Government should make it mandatory for entrepreneurs to keep proper books of account and prepare financial statement for performance monitoring.

- Entrepreneurs should be in position to take reasonable decision. 


\section{References}

Accounting Education Change commission (1990), position statement No. One "Objectives of Education for Accountant ", USA

Akande, 0.0 (2011) "Accounting skills as a performance actor for small business in Nigeria", Journal of Emerging Trends in Economics and management studies (JETEMs0 2, (5) Oyo state.

Brown , B. J. \& Clow, K, W. (1992) introduction to business our business and economic world, California , Macmillan/ McGraw Hills.

Eke, N, (2007) NASMR Restates call for the establishment of SMEs: Bank; The Nation Newspapers, wed $2^{\text {nd }}$ May p.31

Kanu, I. N. and Nwaiwu, B. N. (2010) Entrepreneurship: Essential themes in theory and practices, Owerri: Great Stars problems international.

Owualah, S. I. (1987) providing necessary economic infrastructure for small Business; Antsem pp . 10-30

Vea, C.H. (1980) New venture, strategies, Eaglewood, Cliffs, N. J. Prentice Hall.

Adegite, E. O (2010), Accounting, accountability and national development, The Nigerian Accountant, Jan/ Mar, (43. 1).

Ajibolade , S. O (2008). A survey of the perception of ethical behavior of future Nigerian Accounting professionals, The Nigerian Accounting, July/ sept, (41.3).

Amaechi, A. E Robinson, J.c and Anyikude, N. A (2009),

Entrepreneurship development: principles and practice, $1^{\text {st }}$ ed, Owerri: Roik divine publishers.

Arogundade, B.B (2011), Entrepreneurship Education: An imperative for susutainable development in Nigeria. Journal of emerging trends in educational research and policy university studies of Ado- Ekiti.

Evbodahe, J. I (2009), Global trends in the accountancy profession, in the Nigerian accountant, Oct/ Dec, $(42,4)$.

Fijio. K and Obi, B. c (2012), Entrepreneurship development, $1^{\text {st }}$ ed, Enugu: Hipuvs additional press co.

Hongran, C. T (1977) Cost accounting: A managerial emphasis $4^{\text {th }}$ ed, New jersey : Englewood Clitts.

Isah, E. A and Fadunmi, M (2009), managing schools in a period of economic meltdown, European Journal of social science, $(6,4)$ university of Ibadan.

Izedonmi, F . (2008), Entrepreneurship and wealth creation. The Nigerian accountant, April/ June , (41.2) 